\title{
NITROGEN AND PHOSPHORUS DATA FOR SURFACE WATER IN THE UPPER COLORADO RIVER BASIN, COLORADO, 1980-94
}

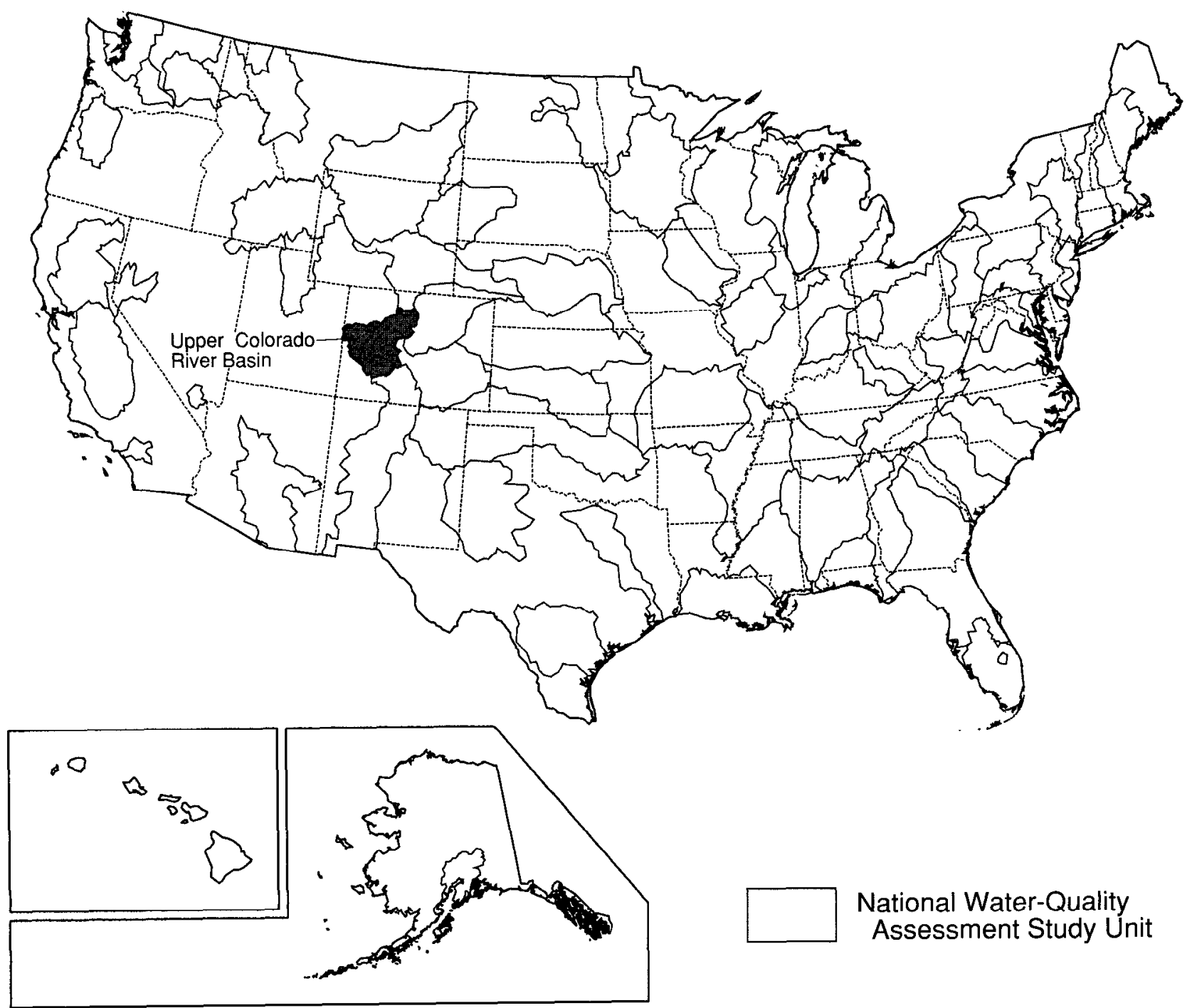

U.S. GEOLOGICAL SURVEY

Open-File Report 97-233

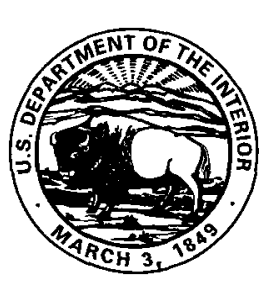

NATIONAL WATER-QUALITY ASSESSMENT PROGRAM 


\section{Nitrogen and Phosphorus Data for Surface Water in the Upper Colorado River Basin, Colorado, 1980-94}

By Kirby H. Wynn and Norman E. Spahr

U.S. GEOLOGICAL SURVEY

Open-File Report 97-233

Denver, Colorado 1997

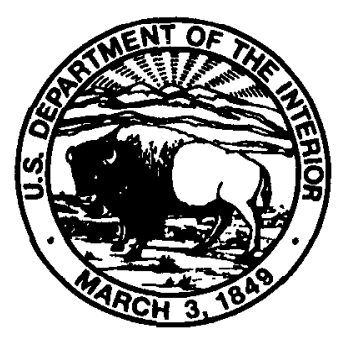




\section{U.S. DEPARTMENT OF THE INTERIOR \\ BRUCE BABBITT, Secretary}

\section{U.S. GEOLOGICAL SURVEY}

Gordon P. Eaton, Director

The use of firm, trade, and brand names in this report is for identification purposes only and does not constitute endorsement by the U.S. Geological Survey.

For additional information write to:

District Chief

U.S. Geological Survey

Box 25046, Mail Stop 415

Denver Federal Center

Denver, CO 80225-0046
Copies of this report can be purchased from:

U.S. Geological Survey

Information Services

Box 25286

Federal Center

Denver, CO 80225 


\section{FOREWORD}

The mission of the U.S. Geological Survey (USGS) is to assess the quantity and quality of the earth resources of the Nation and to provide information that will assist resource managers and policymakers at Federal, State, and local levels in making sound decisions. Assessment of water-quality conditions and trends is an important part of this overall mission.

One of the greatest challenges faced by waterresources scientists is acquiring reliable information that will guide the use and protection of the Nation's water resources. That challenge is being addressed by Federal, State, interstate, and local water-resource agencies and by many academic institutions. These organizations are collecting water-quality data for a host of purposes that include: compliance with permits and water-supply standards; development of remediation plans for specific contamination problems; operational decisions on industrial, wastewater, or watersupply facilities; and research on factors that affect water quality. An additional need for water-quality information is to provide a basis on which regionaland national-level policy decisions can be based. Wise decisions must be based on sound information. As a society we need to know whether certain types of water-quality problems are isolated or ubiquitous, whether there are significant differences in conditions among regions, whether the conditions are changing over time, and why these conditions change from place to place and over time. The information can be used to help determine the efficacy of existing waterquality policies and to help analysts determine the need for and likely consequences of new policies.

To address these needs, the U.S. Congress appropriated funds in 1986 for the USGS to begin a pilot program in seven project areas to develop and refine the National Water-Quality Assessment (NAWQA) Program. In 1991, the USGS began full implementation of the program. The NAWQA Program builds upon an existing base of water-quality studies of the USGS, as well as those of the Federal, State, and local agencies.

The objectives of the NAWQA Program are to

oDescibe current water-quality conditions for a

large part of the Nation's treshwater streams, rivers, and aquifers.
- Describe how water quality is changing over time.

- Improve understanding of the primary natural and human factors that affect water-quality conditions.

This information will help support the development and evaluation of management, regulatory, and monitoring decisions by other Federal, State, and local agencies to protect, use, and enhance water resources.

The goals of the NAWQA Program are being achieved through ongoing and proposed investigations of 59 of the Nation's most important river basins and aquifer systems, which are referred to as study units. These study units are distributed throughout the Nation and cover a diversity of hydrogeologic settings. More than two-thirds of the Nation's freshwater use occurs within the 59 study units and more than twothirds of the people served by public water-supply systems live within their boundaries.

National synthesis of data analysis, based on aggregation of comparable information obtained from the study units, is a major component of the program. This effort focuses on selected water-quality topics using nationally consistent information. Comparative studies will explain differences and similarities in observed water-quality conditions among study areas and will identify changes and trends and their causes. The first topics addressed by the national synthesis are pesticides, nutrients, volatile organic compounds, and aquatic biology. Discussions on these and other waterquality topics will be published in periodic summaries of the quality of the Nation's ground and surface water as the information becomes available.

This report is an element of the comprehensive body of information developed as part of the NAWQA Program. The program depends heavily on the advice, cooperation, and information from many Federal, State, interstate, Tribal, and local agencies and the public. The assistance and suggestions of all are greatly appreciated.
Robert M. Hirsch Chief Hydrologist 


\section{CONTENTS}

Foreword

Abstract

Introduction

Purpose and Scope

Description of Study Unit

1

Nitrogen and Phosphorus Data

Sources.

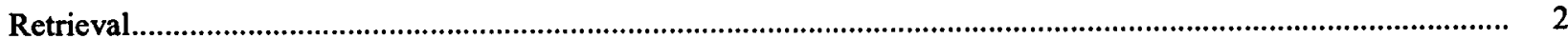

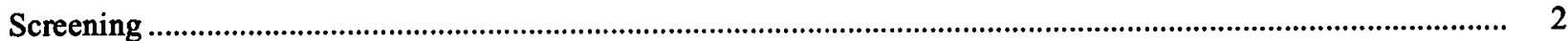

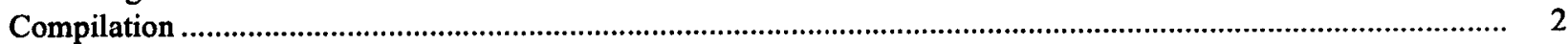

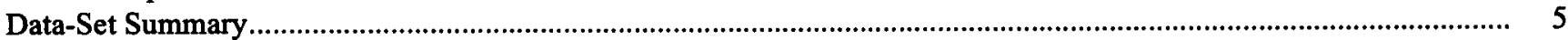

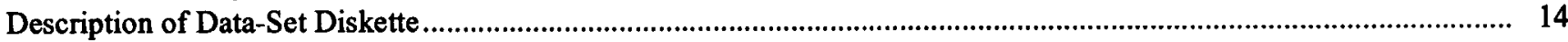

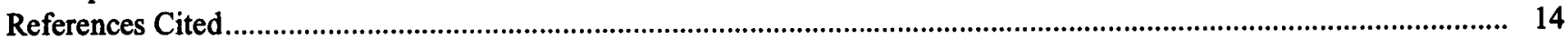

\section{FIGURES}

1. Map showing location of study unit and sampling sites for nutrient data collection .............................................. 3

2. Graph showing distribution of sampling dates for National Water Information System (NWIS) and STOrage and RETrieval (STORET) surface-water sites for nutrient data collection

\section{TABLES}

1. Parameter codes for data compiled on data-set diskette

2. Site identification numbers and site names for map reference numbers in figure 1 .............................................6.6.

3. Number of samples collected per site and number of samples collected per site for each of the five combined nutrient parameters

[Data-Set Diskette in Pocket]

CONVERSION FACTORS AND VERTICAL DATUM

\begin{tabular}{rll}
\hline Multiply & By & To obtain \\
\hline cubic foot per second $\left(\mathrm{ft}^{3} / \mathrm{s}\right)$ & 0.028 & cubic meter per second \\
mile $(\mathrm{mi})$ & 1.609 & kilometer \\
& & \\
\hline
\end{tabular}

Degree Celsius $\left({ }^{\circ} \mathrm{C}\right)$ may be converted to degree Fahrenheit $\left({ }^{\circ} \mathrm{F}\right)$ by using the following equation:

$$
{ }^{\circ} \mathrm{F}=\left(1.8 \times{ }^{\circ} \mathrm{C}\right)+32
$$




\title{
Nitrogen and Phosphorus Data for Surface Water in the Upper Colorado River Basin, Colorado, 1980-94
}

\author{
By Kirby H. Wynn and Norman E. Spahr
}

\begin{abstract}
This report documents, summarizes, and provides on 3.5-in. diskette the surface-water data collected from January 1980 through August 1994 for nitrogen and phosphorus in the Upper Colorado River Basin from the ColoradoUtah State line to the Continental Divide. Ancillary data for parameters, such as water temperature, streamflow, specific conductance, dissolved oxygen, $\mathrm{pH}$, and alkalinity, also are compiled, if available. Data were retrieved from the U.S. Geological Survey National Water Information System and the U.S. Environmental Protection Agency STORET (STOrage and RETrieval) system. The water-quality data are presented for sites having five or more nutrient analyses that reflect ambient stream conditions. The compiled data base contains 4,927 samples from 123 sites. The median sample period of record for individual sites is 2.5 years, and the seventy-fifth percentile is about 12 years. Sixteen sites have only five samples each. The median number of samples per site is 14 samples, whereas the seventy-fifth percentile is 65 samples. The compiled data set was used in the design of a basinwide sampling network that incorporates sites that lack historic surface-water-quality data.
\end{abstract}

\section{INTRODUCTION}

The Upper Colorado River Basin (UCOL) is 1 of 59 U.S. Geological Survey (USGS) National Water-Quality Assessment (NAWQA) study units. The UCOL study began in October 1993 (Driver,
1994). A major part of each NAWQA study is retrospective analysis of existing water-quality data. The four goals of the retrospective analysis are:

1. Develop an improved conceptual model of spatial and temporal patterns of concentrations and loads within the study unit;

2. Guide additional data collection;

3. Contribute data to the National Synthesis Program of NAWQA; and

4. Document findings for future NAWQA work.

The UCOL study-unit team has done a retrospective analysis of available surface-water data for nitrogen and phosphorus, which are essential nutrients for plant and animal growth. Results of nutrient retrospective analysis have guided the design of the UCOL surface-water-quality sampling network. Many of the selected sampling sites lack historic water-quality data (Spahr and others, 1996), and one of the priorities of network design was to select some sites without current or historic water-quality monitoring to expand the spatial extent of available data.

\section{Purpose and Scope}

This report documents, summarizes, and provides on 3.5-in. diskette the surface-water nutrient data that were collected from January 1980 through August 1994. Interpretive analyses of the data are in Spahr and Wynn (1997). Ancillary data for parameters, such as water temperature, streamflow, specific conductance, dissolved oxygen, $\mathrm{pH}$, and alkalinity, also are included on the data diskette, if available, but are not summarized in this report. The compiled data base contains 4,927 samples from 123 sites. 


\section{Description of Study Unit}

The UCOL study unit (fig. 1) consists of the Colorado River and its tributaries that drain the mountains of central and western Colorado. The major tributaries to the Colorado River within the study unit are the Blue, Eagle, Roaring Fork, and Gunnison Rivers. The Colorado River, the largest river within the study-unit basin, flows southwest for about $230 \mathrm{mi}$ from its headwaters in the mountains of central Colorado to the Colorado-Utah State line.

Land use is the major factor affecting nutrient loading within the study unit. Areas that have a rapidly developing infrastructure to support recreational activities within the Fraser and Eagle River Basins and agricultural areas within the Grand Valley and lower Gunnison River Basin are most associated with elevated nutrient loading (Spahr and Wynn, 1997). The study unit is primarily rural and has a population of 234,000 people (Bureau of Census, 1990). More than a quarter of the population resides in the immediate vicinity of Grand Junction, Colo. Although not accounted for in Bureau of Census figures, tourism attracts a large influx of people to the basin during summer and winter (Driver, 1994). An extensive analysis of the environmental setting of the UCOL study unit, including land use, physiography, climate, ecoregion, and hydrologic characteristics, is presented in Apodaca and others (1996).

\section{NITROGEN AND PHOSPHORUS DATA}

\section{Sources}

Data used in the surface-water nutrient analyses were obtained from two sources: (1) The USGS National Water Information System (NWIS) (Maddy and others, 1990), and (2) the U.S. Environmental Protection Agency (USEPA) STORET (STOrage and RETrieval) system. The STORET system is used as a repository for water-quality data by many agencies. The following agencies provided data for this report: USGS; Colorado Department of Public Health and Environment; U.S. Department of Agriculture, Forest Service; and Denver Board of Water Commissioners.

\section{Retrieval}

Water-quality data for January 1, 1980, through August 31, 1994, were retrieved for sites within the UCOL study unit. Only records containing data for concentrations of nitrate, ammonia, total nitrogen, total phosphorus, orthophosphate, or a related constituent were retained. Effort was made to exclude sample sites that do not reflect ambient stream conditions; therefore, data collected at point sources are not included in this report. In December 1994, STORET records for sites were retrieved. Updates or changes made to data in the STORET system after December 1994 are not included in this report.

\section{Screening}

Many sites and samples were excluded from the final data set if definitive corrections for erroneous location information, site type, or nutrient data values were not possible. In some instances, data entry errors were discovered and then corrected after verifying data values with the agency that collected the data. The data set was compiled to determine water-quality patterns on a regional scale; therefore, some sites were retained that have only generalized latitude and longitude values. These sites are identifiable by latitude and longitude values that end in "00." Other sites that had comparatively large errors in latitude and longitude or did not represent ambient surface-water conditions were excluded. Additional screening of sites based on quantity of data was performed during data compilation.

\section{Compilation}

The NWIS and STORET data were combined into a single data set for analysis after screening for errors. The parameter codes for the STORET data were converted, as necessary, to their NWIS equivalents before merging the two data sets into a single data base. All the NWIS parameter codes and their definitions in the order that they appear on the data diskette provided with this report are listed in table 1. Additional parameters created during data compilation or analysis are included in table 1 and on the data diskette. 


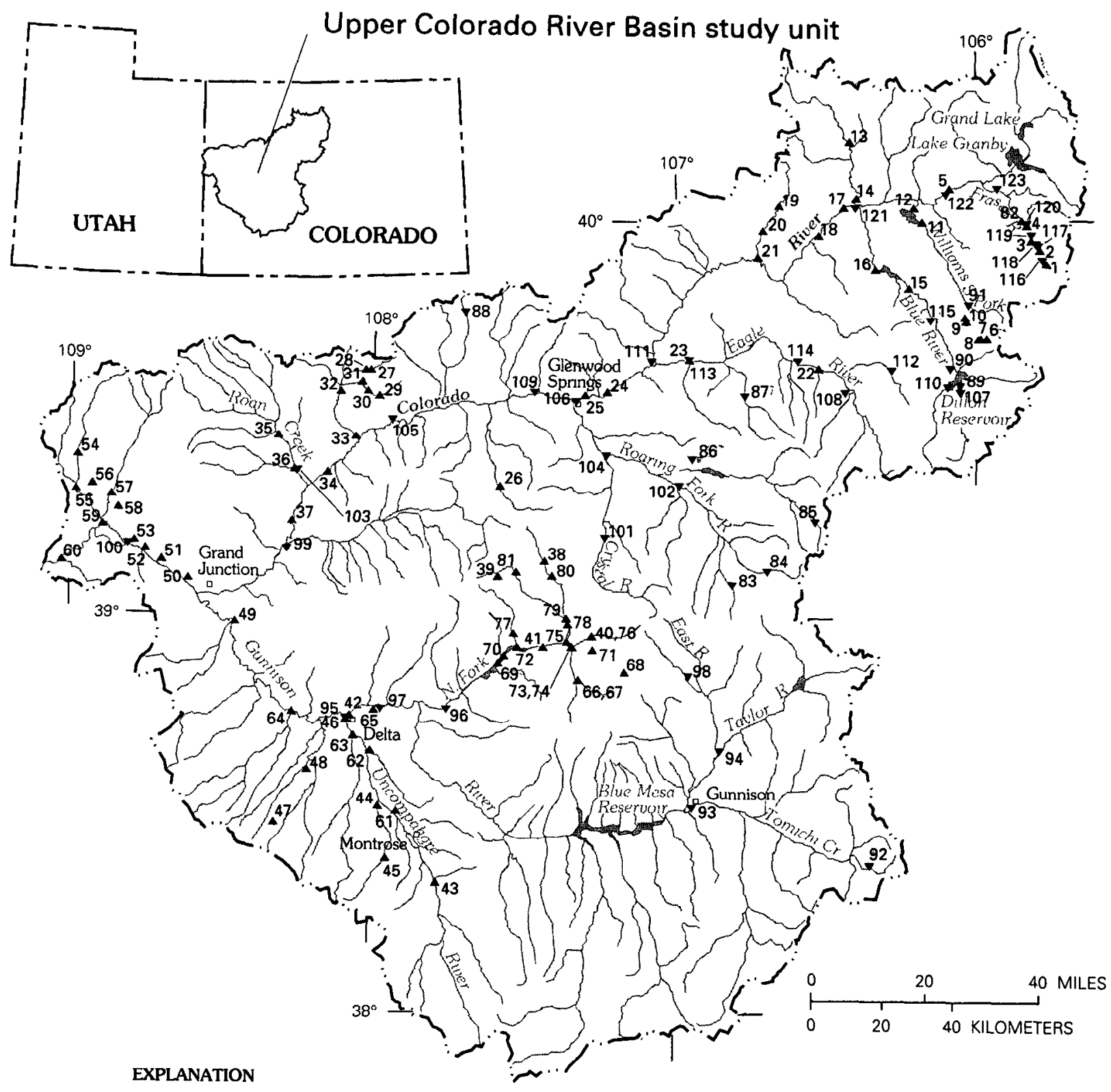

\section{SAMPLING SITES}

INumber designates map reference

number ("mapno" parameter in table 1 and table 2)1

- Data from U.S. Geological Survey National Water Information System

- Data from U.S. Environmental Protection Agency STOrage and RETrieval System

Flgure 1. Location of study unit and sampling sites for nutrient data collection. 
Table 1. Parameter codes for data compiled on data-set diskette

[mg/L, milligrams per liter; $\mu \mathrm{S} / \mathrm{cm}$, microsiemens per centimeter at 25 degrees Celsius; $\mathrm{N}$, nitrogen; $\mathrm{NH}_{4}$, ammonium ion; $\mathrm{NO}_{3}$, nitrate; $\mathrm{P}$, phosphorus; $\mathrm{PO}_{4}$, phosphate; ${ }^{\circ} \mathrm{C}$, degrees Celsius; $\mathrm{ft}^{3} / \mathrm{s}$, cubic feet per second; $\mathrm{CaCO}_{3}$, calcium carbonate]

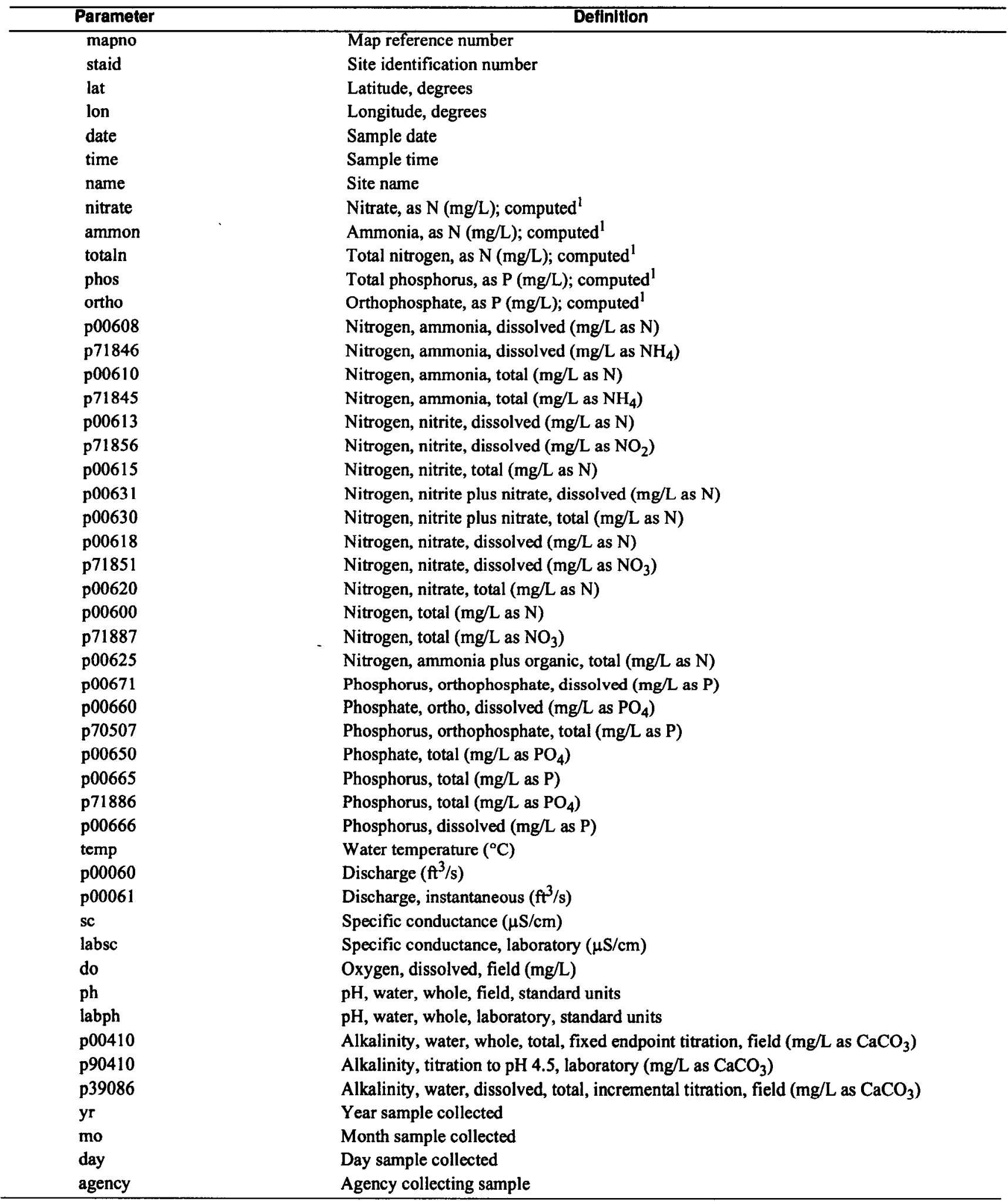

\footnotetext{
${ }^{1}$ Value computed from a related parameter field using method of Mueller and others (1995, p. 7$)$.
} 
Because many agencies collected the data for different purposes, nutrient parameters are reported in numerous ways. Nutrient parameters were combined to reduce the total number from 20 to a more manageable 5 for data-analysis purposes. Procedures described by Mueller and others (1995, p. 7) for combining nutrient parameters were followed. The combined nutrient parameters summarized in this report, included on the data diskette with other nutrient and ancillary data, and used in interpretive work by Spahr and Wynn (1997) are:

- Nitrate as nitrogen (hereinafter referred to as nitrate).

- Ammonia as nitrogen (hereinafter referred to as ammonia).

- Total nitrogen as nitrogen (hereinafter referred to as total nitrogen).

- Total phosphorus as phosphorus (hereinafter referred to as total phosphorus).

- Orthophosphate as phosphorus (hereinafter referred to as orthophosphate).

The data set was screened to include only sites that had a minimum of five observations for at least one of the five nutrients listed above. The resulting data set contains 4,927 samples at 123 sites located within the UCOL study unit. The locations of these 123 sites are shown in figure 1 . The sites labeled with map reference numbers 1 through 82 are from the USGS NWIS data base, and the remaining 41 sites are from the USEPA STORET data base. Map reference number, site number, and site name for each of the 123 sites that met data-screening criteria are listed in table 2. The data set presented here was used for analysis of the spatial distribution, relation to land use, and temporal trends of nutrient concentrations in surface waters of the UCOL study unit. However, because of especially restrictive data requirements, temporal trend analysis was possible for fewer than 10 percent of the sites for each of the five combined nutrient parameters.

\section{DATA-SET SUMMARY}

The selected set of 123 sampling sites for analyzing surface-water quality has widely varying sampling periods. The sample-collection dates range from January 7,1980 , to August 29,1994 . The median sample period of record for individual sites is only 2.5 years, whereas the seventy-fifth percentile is about 12 years. The distribution of sampling dates for the USGS NWIS (map reference numbers 1-82) and USEPA STORET (map reference numbers 83-123) sites where nutrient data were collected are shown in figure 2 .

It is important to determine the similarity of sampling frequency and period of record before attempting to compare data values between sites. Sites 11 and 12 on the Williams Fork and sites 15 and 16 on the Blue River were sampled for short, but concurrent, time intervals and would, therefore, be good sites for comparing water quality between the two rivers. However, comparison of the data for these four sites with data from site 63 on Dry Creek, near Delta, Colo., would be misleading because data for site 63 were collected several years later. Sites 49 and 60 were appropriate choices for determining water-quality trends, in part, because they each have many samples collected over a 14.5-year period.

The number of samples and the number of samples collected for each of the five combined nutrient parameters (nitrate, ammonia, total nitrogen, total phosphorus, and orthophosphate) are listed, by site, in table 3. The total number of samples for the whole data set and for each of the five combined nutrient parameters is listed in the last row of table 3. None of the sites have data for all five nutrients for each and every sample. Therefore, for a given site, the number of samples in column 2 of table 3 usually is greater than the number of samples collected for nitrate, ammonia, total nitrogen, total phosphorus, or orthophosphate. Site 22 is typical: the number of samples is 76 but there are only 50 nitrate, 1 ammonia, 0 total nitrogen, 0 total phosphorus, and 69 orthophosphate samples. The number of samples per site is variable. Because sites retained must have at least five samples for one of the combined nutrients, the minimum number of samples listed in table 3 is five. Sixteen of the sites (about 13 percent) have only 5 samples. The median number of samples per site is 14 samples, whereas the seventy-fifth percentile is 65 samples. Site 100, Colorado River near Loma, has the most samples (263), collected from 1980 to 1992 . 
Table 2. Site identification numbers and site names for map reference numbers in figure 1

[Map reference number is the parameter "mapno" in table 1 and on data diskette; site identification number is the parameter "staid" in table 1 and on data diskette; site name is the parameter "name" in table 1 and on data diskette]

\begin{tabular}{|c|c|c|}
\hline $\begin{array}{c}\text { Map } \\
\text { reference } \\
\text { number }\end{array}$ & $\begin{array}{c}\text { Site } \\
\text { Identlfication } \\
\text { number }\end{array}$ & $\begin{array}{c}\text { Site } \\
\text { name }\end{array}$ \\
\hline 1 & 09023750 & Fraser River below Buck Creek at Winter Park, CO \\
\hline 2 & 09025010 & Fraser River below Vasquez Creek at Winter Park, CO \\
\hline 3 & 09027010 & Fraser River below St. Louis Creek at Fraser, CO \\
\hline 4 & 09027100 & Fraser River at Tabernash, $\mathrm{CO}$ \\
\hline 5 & 09034500 & Colorado River at Hot Sulphur Springs, CO \\
\hline 6 & 09035830 & South Fork Williams Fork near Ptarmigan Pass, CO \\
\hline 7 & 09035840 & South Fork Williams Fork above tributary near Ptarmigan Pass, CO \\
\hline 8 & 09035850 & South Fork Williams Fork above Short Creek near Ptarmigan Pass, CO \\
\hline 9 & 09035870 & South Fork Williams Fork below Short Creek near Ptarmigan Pass, CO \\
\hline 10 & 09035880 & South Fork Williams Fork below Old Baldy Mountain near Leal, CO \\
\hline 11 & 09037500 & Williams Fork near Parshall, CO \\
\hline 12 & 09038500 & Williams Fork below Williams Fork Reservoir, $\mathrm{CO}$ \\
\hline 13 & 09041090 & Muddy Creek above Antelope Creek near Kremmling, CO \\
\hline 14 & 09041500 & Muddy Creek at Kremmling, $\mathrm{CO}$ \\
\hline 15 & 09053500 & Blue River above Green Mountain Reservoir, CO \\
\hline 16 & 09057500 & Blue River below Green Mountain Reservoir, CO \\
\hline 17 & 09058000 & Colorado River near Kremmling, $\mathrm{CO}$ \\
\hline 18 & 09058030 & Colorado River near Radium, CO \\
\hline 19 & 09060500 & Rock Creek near Toponas, CO \\
\hline 20 & 09060550 & Rock Creek at Crater, CO \\
\hline 21 & 09060770 & Rock Creek at McCoy, CO \\
\hline 22 & 09067000 & Beaver Creek at Avon, $\mathrm{CO}$ \\
\hline 23 & 09069000 & Eagle River at Gypsum, CO \\
\hline 24 & 09071100 & Colorado River near Glenwood Springs, CO \\
\hline 25 & 09071750 & Colorado River above Glenwood Springs, CO \\
\hline 26 & 09089500 & West Divide Creek near Raven, CO \\
\hline 27 & 09092830 & Northwater Creek near Anvil Points, CO \\
\hline 28 & 09092850 & East Middle Fork Parachute Creek near Rio Blanco, CO \\
\hline 29 & 09092960 & East Fork Parachute Creek near Anvil Points, CO \\
\hline 30 & 09092970 & East Fork Parachute Creek near Rulison, CO \\
\hline 31 & 09092980 & Ben Good Creek near Rulison, CO \\
\hline 32 & 09093000 & Parachute Creek near Parachute, CO \\
\hline 33 & 09093500 & Parachute Creek at Parachute, $\mathrm{CO}$ \\
\hline 34 & 09093700 & Colorado River near De Beque, CO \\
\hline 35 & 09095000 & Roan Creek near De Beque, CO \\
\hline 36 & 09095400 & Dry Fork near De Beque, CO \\
\hline 37 & 09095500 & Colorado River near Cameo, $\mathrm{CO}$ \\
\hline 38 & 09129800 & Clear Fork near Ragged Mountain, $\mathrm{CO}$ \\
\hline 39 & 09131100 & Cow Creek near Paonia, CO \\
\hline $40^{\circ}$ & 09132050 & Anthracite Creek near Somerset, CO \\
\hline 41 & 09132500 & North Fork Gunnison River near Somerset, CO \\
\hline
\end{tabular}


Table 2. Site identification numbers and site names for map reference numbers in figure 1-Continued

[Map reference number is the parameter "mapno" in table 1 and on data diskette; site identification number is the parameter "staid" in table 1 and on data diskette; site name is the parameter "name" in table 1 and on data diskette]

\begin{tabular}{|c|c|c|}
\hline $\begin{array}{c}\text { Map } \\
\text { reference } \\
\text { number }\end{array}$ & $\begin{array}{c}\text { Site } \\
\text { Identification } \\
\text { number }\end{array}$ & $\begin{array}{c}\text { Site } \\
\text { name }\end{array}$ \\
\hline 42 & 09144250 & Gunnison River at Delta, CO \\
\hline 43 & 09147500 & Uncompahgre River at Colona, $\mathrm{CO}$ \\
\hline 44 & 09149400 & Spring Creek near Beaver Hill, CO \\
\hline 45 & 09149420 & Spring Creek near Montrose, CO \\
\hline 46 & 09149500 & Uncompahgre River at Delta, $\mathrm{CO}$ \\
\hline 47 & 09149900 & Potter Creek near Columbine Pass, CO \\
\hline 48 & 09149910 & Potter Creek near Olathe, $\mathrm{CO}$ \\
\hline 49 & 09152500 & Gunnison River near Grand Junction, CO \\
\hline 50 & 09152650 & Leach Creek at Durham, CO \\
\hline 51 & 09152900 & Adobe Creek near Fruita, $\mathrm{CO}$ \\
\hline 52 & 09153270 & Big Salt Wash at Fruita, CO \\
\hline 53 & 09153300 & Reed Wash near Loma, CO \\
\hline 54 & 09153330 & West Salt Creek near Carbonera, CO \\
\hline 55 & 09153400 & West Salt Creek near Mack, CO \\
\hline 56 & 09160500 & Badger Wash Observation Res 12 near Mack, CO \\
\hline 57 & 09163310 & East Salt Creek near Mack, CO \\
\hline 58 & 09163340 & Mack Wash near Mack, CO \\
\hline 59 & 09163490 & Salt Creek near Mack, CO \\
\hline 60 & 09163500 & Colorado River near Colorado-Utah State line \\
\hline 61 & 383041107544201 & Cedar Creek near mouth \\
\hline 62 & 383946107595301 & Loutsenhizer Arroyo near mouth \\
\hline 63 & 384202108032001 & Dry Creek at mouth, near Delta, CO \\
\hline 64 & 384527108152701 & Gunnison River above Escalante Creek, near Delta, CO \\
\hline 65 & 384551107591901 & Unnamed drainage at Highway 92, near Read, $\mathrm{CO}$ \\
\hline 66 & 385033107190300 & Upper Coal Creek near Somerset, CO \\
\hline 67 & 385037107190300 & Cliff Creek near Somerset, CO \\
\hline 68 & 385146107094700 & Ruby Anthracite Creek near Kebler Pass, CO \\
\hline 69 & 385308107345100 & North Fork Gunnison River above Paonia, CO \\
\hline 70 & 385414107334000 & Terror Creek near Paonia, CO \\
\hline 71 & 385506107161400 & Grouse Spring Creek near Marcelling Mountain, CO \\
\hline 72 & 385532107310400 & Lower Hubbard Creek near Bowie, CO \\
\hline 73 & 385534107201900 & Lower Coal Creek near Somerset, CO \\
\hline 74 & 385538107202400 & Lower Anthracite Creek near Somerset, CO \\
\hline 75 & 385626107212000 & Muddy Creek below Paonia Reservoir, CO \\
\hline 76 & 385712107162600 & Upper Anthracite Creek near Somerset, $\mathrm{CO}$ \\
\hline 77 & 385741107315100 & Upper Hubbard Creek near Bowie, CO \\
\hline 78 & 385903107210800 & Muddy Creek above Paonia Reservoir, CO \\
\hline 79 & 390000107212700 & Lower West Muddy Creek near Paonia Reservoir, CO \\
\hline 80 & 390620107241900 & East Muddy Creek near Ragged Mountain, CO \\
\hline 81 & 390658107312500 & West Muddy Creek near West Muddy Creek Ranger Station, CO \\
\hline 82 & 400009105504600 & Fraser River below Crooked Creek at Tabernash, $\mathrm{CO}$ \\
\hline
\end{tabular}


Table 2. Site identification numbers and site names for map reference numbers in figure 1 -Continued

[Map reference number is the parameter "mapno" in table 1 and on data diskette; site identification number is the parameter "staid" in table 1 and on data diskette; site name is the parameter "name" in table 1 and on data diskette]

\begin{tabular}{|c|c|c|}
\hline $\begin{array}{c}\text { Map } \\
\text { reference } \\
\text { number }\end{array}$ & $\begin{array}{c}\text { Site } \\
\text { Identification } \\
\text { number }\end{array}$ & $\begin{array}{c}\text { Site } \\
\text { name }\end{array}$ \\
\hline $1_{83}$ & FS021547A020001 & Lower Castle Creek SI 980 \\
\hline 84 & FS021545A030001 & Lower Lincoln Creek SI 876 \\
\hline 85 & FS021541S040002 & Marten Creek SI 8 \\
\hline 86 & FS021543S020001 & Lower Taylor Creek SI 799 \\
\hline 87 & FS021535E010001 & Lower Brush Creek SI 1471.5 \\
\hline 88 & FS021563R010001 & Three Forks Creek SI 494 \\
\hline 89 & 002102 & So Plat Dillon Res Blue R@Res \\
\hline 90 & 2501 & Straight Creek at Res near Dillon, CO \\
\hline 91 & 003106 & Williams Fork No 8 at Sugarloaf CMPGD \\
\hline 92 & 000149 & Indian Creek near Sargents \\
\hline 93 & 000059 & Tomichi Creek at Gunnison \\
\hline 94 & 000078 & East River at confl. with Taylor \\
\hline 95 & 000055 & Uncompahgre River at Delta \\
\hline 96 & 000100 & N Fk of Gunnison below Hotchkiss \\
\hline 97 & 000056 & Gunnison River near Delta \\
\hline 98 & 000151 & Slate River below Crested Butte \\
\hline 99 & 000048 & Colorado River near Cameo \\
\hline 100 & 000050 & Colorado River near Loma \\
\hline 101 & 000145 & Crystal River at Redstone \\
\hline 102 & 000144 & Roaring Fork River below Aspen \\
\hline 103 & 000148 & Roan Creek near De Beque \\
\hline 104 & 000146 & Crystal River near mouth \\
\hline 105 & 000147 & Colorado River at Rulison \\
\hline 106 & 000053 & Roaring Fork at mouth \\
\hline 107 & 000115 & Blue River above Dillon Resevoir \\
\hline 108 & 000118 & Cross Creek Ar con. with Eagle \\
\hline 109 & 000047 & Colorado River at New Castle \\
\hline 110 & 000141 & Ten Mile Creek at Frisco \\
\hline 111 & 000046 & Colorado River near Dotsero \\
\hline 112 & 000074 & Gore Creek at mouth \\
\hline 113 & 000052 & Eagle River at Gypsum \\
\hline 114 & 000076 & Eagle River at town of Edwards \\
\hline 115 & 000098 & Blue River below Dillon Resevoir \\
\hline 116 & 000FR3 & Fraser River at USGS Gauge \\
\hline 117 & 000FR4 & Fraser above Grand WWTP \\
\hline 118 & 000FR6 & Fraser below Grand WWTP \\
\hline 119 & 000FR7 & Fraser River above Fraser WWTP \\
\hline 120 & 00FR10 & Fraser near Tabernsh \\
\hline 121 & 000099 & Blue River near confluence with Colorado River \\
\hline 122 & 000045 & Colorado River near Hot Sulfur Springs \\
\hline 123 & 000139 & Fraser River near Granby \\
\hline
\end{tabular}

'The site names for map reference numbers 83-123 are spelled as they appear in the U.S. Environmental Protection Agency's STORET (STOrage and RETrieval) system.

8 Nitrogen and Phosphorus Data for Surface Water in the Upper Colorado Rlver Basin, Colorado, $1980-94$ 


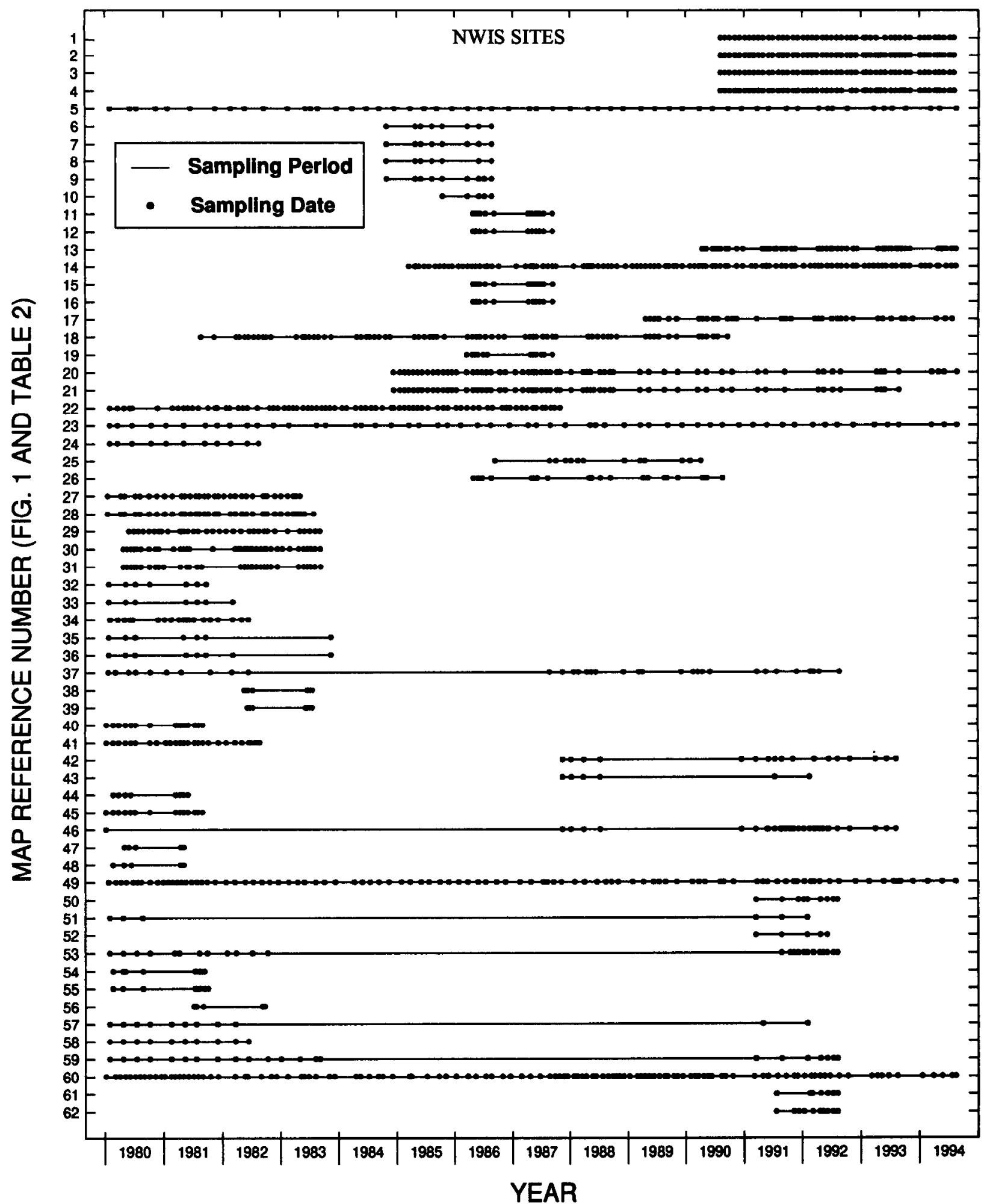

Figure 2. Distribution of sampling dates for National Water Information System (NWIS) and STOrage and RETrieval (STORET) surface-water sites for nutrient data collection. 


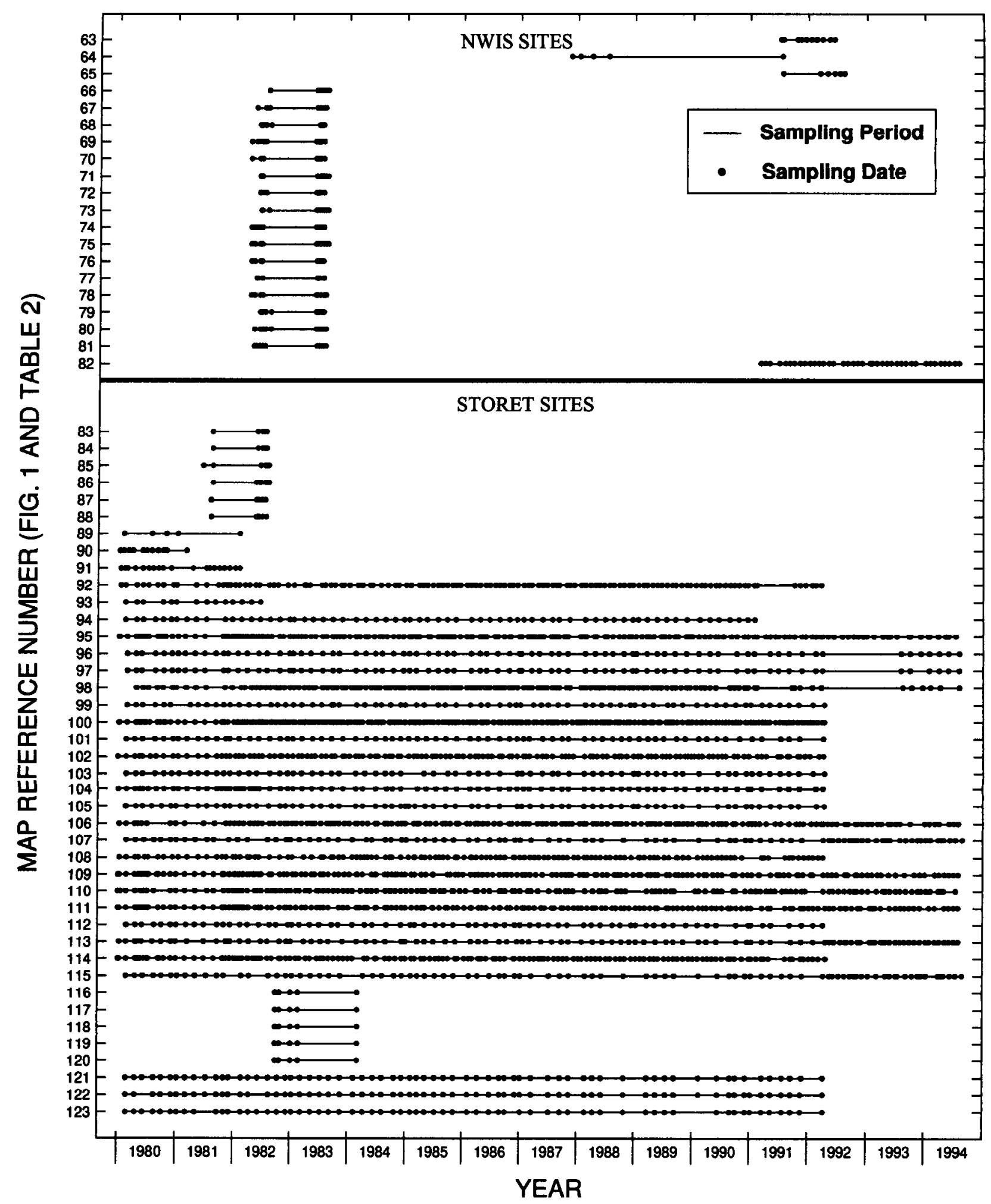

Figure 2. Distribution of sampling dates for National Water Information System (NWIS) and STOrage and RETrieval (STORET) surface-water sites for nutrient data collection-Continued. 
Table 3. Number of samples collected per site and number of samples collected per site for each of the five combined nutrient parameters

[Map reference number is the parameter "mapno" in table 1 and data diskette]

\begin{tabular}{|c|c|c|c|c|c|c|}
\hline \multirow{2}{*}{$\begin{array}{c}\text { Map } \\
\text { reference } \\
\text { number }\end{array}$} & \multirow[b]{2}{*}{$\begin{array}{c}\text { Number of } \\
\text { samples }\end{array}$} & \multicolumn{5}{|c|}{ Combined nutrient parameters } \\
\hline & & $\begin{array}{l}\text { Nitrate } \\
\text { samples }\end{array}$ & $\begin{array}{c}\text { Ammonla } \\
\text { samples }\end{array}$ & $\begin{array}{l}\text { Total nitrogen } \\
\text { samples }\end{array}$ & $\begin{array}{c}\text { Total phosphorus } \\
\text { samples }\end{array}$ & $\begin{array}{c}\text { Orthophosphate } \\
\text { samples }\end{array}$ \\
\hline 1 & 47 & 45 & 47 & 0 & $\mathbf{0}$ & 1 \\
\hline 2 & 61 & 59 & 61 & 0 & $\mathbf{0}$ & 2 \\
\hline 3 & 48 & 47 & 48 & 0 & $\mathbf{0}$ & 1 \\
\hline 4 & 60 & 60 & 60 & $\mathbf{0}$ & 0 & 1 \\
\hline 5 & 58 & 24 & 16 & 56 & 57 & 16 \\
\hline 6 & 8 & 8 & 8 & 0 & $\mathbf{0}$ & 7 \\
\hline 7 & 8 & 8 & 8 & 0 & 0 & 6 \\
\hline 8 & 7 & 7 & 7 & 0 & 0 & 5 \\
\hline 9 & 9 & 8 & 9 & 0 & 0 & 8 \\
\hline 10 & 5 & 4 & 5 & 0 & 0 & 4 \\
\hline 11 & 13 & 1 & 13 & 11 & 13 & 13 \\
\hline 12 & 12 & 5 & 12 & 12 & 12 & 12 \\
\hline 13 & 49 & 11 & 49 & 47 & 49 & 49 \\
\hline 14 & 118 & 56 & 117 & 116 & 117 & 104 \\
\hline 15 & 13 & 10 & 13 & 13 & 13 & 13 \\
\hline 16 & 12 & 11 & 12 & 12 & 12 & 12 \\
\hline 17 & 35 & 23 & 35 & 33 & 35 & 35 \\
\hline 18 & 69 & 21 & 12 & 65 & 68 & 69 \\
\hline 19 & 12 & 2 & 12 & 12 & 12 & 12 \\
\hline 20 & 64 & 28 & 64 & 46 & 56 & 52 \\
\hline 21 & 61 & 28 & 61 & 51 & 57 & 49 \\
\hline 22 & 76 & 50 & 1 & 0 & 0 & 69 \\
\hline 23 & 57 & 53 & 15 & 55 & 57 & 16 \\
\hline 24 & 14 & 8 & 0 & 11 & 14 & 1 \\
\hline 25 & 13 & 13 & 0 & 0 & 0 & 0 \\
\hline 26 & 20 & 2 & 20 & 15 & 20 & 20 \\
\hline 27 & 32 & 25 & 0 & 0 & 0 & 30 \\
\hline 28 & 33 & 26 & 0 & 0 & 0 & 32 \\
\hline 29 & 33 & 30 & 0 & 0 & 0 & 31 \\
\hline 30 & 37 & 28 & 1 & 0 & 0 & 33 \\
\hline 31 & 33 & 31 & 0 & 0 & 0 & 28 \\
\hline 32 & 7 & 7 & 0 & 7 & 7 & 1 \\
\hline 33 & 7 & 7 & 1 & 6 & 7 & 1 \\
\hline 34 & 19 & 19 & 0 & 0 & 0 & 0 \\
\hline 35 & 8 & 8 & 0 & 7 & 7 & 1 \\
\hline 36 & 8 & 7 & 1 & 6 & 7 & 1 \\
\hline 37 & 33 & 31 & 3 & 9 & 10 & 3 \\
\hline 38 & 6 & 5 & 0 & 0 & 6 & 0 \\
\hline 39 & 7 & 4 & 0 & 0 & 7 & 0 \\
\hline 40 & 14 & 12 & 0 & 14 & 14 & 0 \\
\hline 41 & 29 & 18 & 8 & 24 & 27 & 0 \\
\hline 42 & 17 & 17 & 13 & 9 & 9 & 13 \\
\hline
\end{tabular}


Table 3. Number of samples collected per site and number of samples collected per site for each of the five combined nutrient parameters-Continued

[Map reference number is the parameter "mapno" in table 1 and data diskette]

\begin{tabular}{|c|c|c|c|c|c|c|}
\hline \multirow{2}{*}{$\begin{array}{c}\text { Map } \\
\text { reference } \\
\text { number }\end{array}$} & \multirow{2}{*}{$\begin{array}{l}\text { Number of } \\
\text { samples }\end{array}$} & \multicolumn{5}{|c|}{ Combined nutrient parameters } \\
\hline & & $\begin{array}{l}\text { Niltrate } \\
\text { samples }\end{array}$ & $\begin{array}{l}\text { Ammonia } \\
\text { samples }\end{array}$ & $\begin{array}{c}\text { Total nitrogen } \\
\text { samples }\end{array}$ & $\begin{array}{l}\text { Total phosphorus } \\
\text { samples }\end{array}$ & $\begin{array}{c}\text { Orthophosphate } \\
\text { samples }\end{array}$ \\
\hline 43 & 6 & 6 & 1 & $\mathbf{0}$ & $\mathbf{0}$ & 1 \\
\hline 44 & 8 & 6 & 0 & 8 & 8 & 0 \\
\hline 45 & 14 & 14 & 0 & 13 & 13 & 0 \\
\hline 46 & 30 & 30 & 13 & 9 & 9 & 14 \\
\hline 47 & 5 & 5 & 0 & 0 & 0 & 0 \\
\hline 48 & 5 & 5 & $\mathbf{0}$ & $\mathbf{0}$ & 0 & 0 \\
\hline 49 & 97 & 97 & 75 & 94 & 94 & 76 \\
\hline 50 & 9 & 9 & 2 & 0 & 0 & 2 \\
\hline 51 & 6 & 6 & 2 & 0 & 0 & 2 \\
\hline 52 & 5 & 5 & 2 & 0 & 0 & 2 \\
\hline 53 & 24 & 24 & 2 & 0 & 0 & 1 \\
\hline 54 & 20 & 20 & 0 & 0 & $\mathbf{0}$ & 2 \\
\hline 55 & 9 & 9 & 0 & $\mathbf{0}$ & $\mathbf{0}$ & $\mathbf{0}$ \\
\hline 56 & 15 & 15 & $\mathbf{0}$ & $\mathbf{0}$ & $\mathbf{0}$ & 2 \\
\hline 57 & 11 & 10 & 1 & $\mathbf{0}$ & $\mathbf{0}$ & 1 \\
\hline 58 & 10 & 10 & 0 & 0 & $\mathbf{0}$ & $\mathbf{0}$ \\
\hline 59 & 22 & 22 & 2 & 0 & 0 & 2 \\
\hline 60 & 120 & 120 & 79 & 97 & 98 & 79 \\
\hline 61 & 7 & 7 & 1 & $\mathbf{0}$ & $\mathbf{0}$ & 1 \\
\hline 62 & 10 & 10 & 2 & 0 & 0 & 1 \\
\hline 63 & 11 & 11 & 2 & 0 & $\mathbf{0}$ & 2 \\
\hline 64 & 5 & 5 & 1 & 0 & 0 & 1 \\
\hline 65 & 6 & 6 & 1 & $\mathbf{0}$ & 0 & 1 \\
\hline 66 & 7 & 6 & 0 & 0 & 3 & 0 \\
\hline 67 & 8 & 6 & 0 & 0 & 4 & 0 \\
\hline 68 & 7 & 5 & 0 & 0 & 6 & 0 \\
\hline 69 & 10 & 9 & 0 & 0 & 7 & 0 \\
\hline 70 & 8 & 7 & 0 & 0 & 7 & 0 \\
\hline 71 & 8 & 7 & 0 & 0 & 5 & 0 \\
\hline 72 & 8 & 6 & 0 & 0 & 7 & 0 \\
\hline 73 & 10 & 9 & 0 & 0 & 6 & 0 \\
\hline 74 & 10 & 10 & 0 & 0 & 6 & 0 \\
\hline 75 & 12 & 11 & 0 & 0 & 5 & 0 \\
\hline 76 & 9 & 8 & 0 & 0 & 5 & 0 \\
\hline 77 & 5 & 3 & 0 & 0 & 5 & 0 \\
\hline 78 & 10 & 10 & 0 & 0 & 5 & 0 \\
\hline 79 & 9 & 6 & 0 & 0 & 8 & 0 \\
\hline 80 & 11 & 10 & 0 & 0 & 8 & 0 \\
\hline 81 & 10 & 7 & 0 & 0 & 8 & 0 \\
\hline 82 & 39 & 37 & 39 & 0 & 0 & 0 \\
\hline 83 & 5 & 5 & 0 & 0 & 0 & 4 \\
\hline 84 & 5 & 5 & 0 & 0 & 0 & 3 \\
\hline
\end{tabular}


Table 3. Number of samples collected per site and number of samples collected per site for each of the five combined nutrient parameters - Continued

[Map reference number is the parameter "mapno" in table 1 and data diskette]

\begin{tabular}{|c|c|c|c|c|c|c|}
\hline \multirow{2}{*}{$\begin{array}{c}\text { Map } \\
\text { reference } \\
\text { number }\end{array}$} & \multirow{2}{*}{$\begin{array}{l}\text { Number of } \\
\text { samples }\end{array}$} & \multicolumn{5}{|c|}{ Combined nutrlent parameters } \\
\hline & & $\begin{array}{c}\text { Nitrate } \\
\text { samples }\end{array}$ & $\begin{array}{l}\text { Ammonla } \\
\text { samples }\end{array}$ & $\begin{array}{l}\text { Total nltrogen } \\
\text { samples }\end{array}$ & $\begin{array}{c}\text { Total phosphorus } \\
\text { samples }\end{array}$ & $\begin{array}{c}\text { Orthophosphate } \\
\text { samples }\end{array}$ \\
\hline 85 & 6 & 6 & 0 & 0 & 0 & 3 \\
\hline 86 & 7 & 6 & 0 & 0 & $\mathbf{0}$ & 5 \\
\hline 87 & 5 & 5 & 0 & 0 & 0 & 3 \\
\hline 88 & 5 & 5 & 0 & 0 & 0 & 3 \\
\hline 89 & 5 & 5 & 0 & 0 & 4 & 0 \\
\hline 90 & 11 & 11 & 0 & $\mathbf{0}$ & 9 & $\mathbf{0}$ \\
\hline 91 & 19 & 15 & 0 & 0 & 17 & 0 \\
\hline 92 & 124 & 14 & 112 & 11 & 117 & 1 \\
\hline 93 & 14 & 2 & 5 & $\mathbf{0}$ & 14 & $\mathbf{0}$ \\
\hline 94 & 67 & 4 & 56 & 5 & 66 & 0 \\
\hline 95 & 174 & 105 & 154 & 86 & 154 & 0 \\
\hline 96 & 80 & 42 & 69 & 36 & 79 & 0 \\
\hline 97 & 78 & 3 & 68 & 5 & 77 & $\mathbf{0}$ \\
\hline 98 & 129 & 6 & 116 & 8 & 121 & 0 \\
\hline 99 & 75 & 4 & 65 & 14 & 74 & $\mathbf{0}$ \\
\hline 100 & 263 & 78 & 242 & 62 & 235 & $\mathbf{0}$ \\
\hline 101 & 72 & 3 & 60 & 7 & 72 & $\mathbf{0}$ \\
\hline 102 & 137 & 12 & 123 & 8 & 127 & $\mathbf{0}$ \\
\hline 103 & 71 & 58 & 60 & 53 & 70 & $\mathbf{0}$ \\
\hline 104 & 80 & 6 & 66 & 1 & 75 & o \\
\hline 105 & 75 & 3 & 63 & 11 & 73 & $\mathbf{0}$ \\
\hline 106 & 159 & 6 & 133 & 5 & 149 & $\mathbf{0}$ \\
\hline 107 & 92 & 5 & 68 & 2 & 91 & $\mathbf{0}$ \\
\hline 108 & 128 & 6 & 113 & 3 & 124 & 0 \\
\hline 109 & 174 & 8 & 141 & 4 & 154 & 0 \\
\hline 110 & 146 & 34 & 118 & 22 & 137 & 0 \\
\hline 111 & 175 & 10 & 141 & 6 & 156 & 0 \\
\hline 112 & 73 & 35 & 61 & 33 & 71 & 0 \\
\hline 113 & 102 & 29 & 75 & 21 & 99 & 0 \\
\hline 114 & 150 & 32 & 131 & 28 & 134 & 0 \\
\hline 115 & 90 & 5 & 65 & 6 & 90 & 0 \\
\hline 116 & 5 & 2 & 5 & 3 & 0 & $\mathbf{0}$ \\
\hline 117 & 5 & 3 & 5 & 3 & 0 & 0 \\
\hline 118 & 5 & 2 & 5 & 4 & 0 & 0 \\
\hline 119 & 5 & 2 & 5 & 2 & 0 & 0 \\
\hline 120 & 5 & 4 & 5 & 2 & 0 & 0 \\
\hline 121 & 67 & 5 & 56 & 4 & 66 & 0 \\
\hline 122 & 66 & 3 & 56 & 9 & 65 & 0 \\
\hline 123 & 65 & 6 & 55 & 8 & 65 & 0 \\
\hline Total & 4,927 & 2,076 & 3,454 & 1,330 & 3,795 & 963 \\
\hline
\end{tabular}




\section{DESCRIPTION OF DATA-SET DISKETTE}

The MSDOS format 3.5-in. diskette inside the back cover pocket contains the compiled nutrient and ancillary data set in an ASCII text file named ucol.txt. The diskette contains 76 tab-delimited parameter fields, including remark fields, for the 49 parameters listed in table 1 . The data are arranged as one line per unique sample date and time for each site. The data set is sorted sequentially by map reference number, date, and time.

The first line of the file contains the parameter field names in the same order as listed in table 1. The second line of the file defines the type $(n=$ numeric, $s=$ character string, $d=$ date) and width of each parameter field. Data values begin on line 3 of ucol.txt. Water-quality constituents that have a laboratory reporting limit have a separate character field for remark (data censoring) codes. These remark fields are positioned to the left of their associated constituent. All remark fields have the same name as their associated constituent, except the first letter of the remark field is an "r." For example, the remark fields for the nitrate and p00600 parameter fields are rnitrate and r00600, respectively. Constituent concentrations reported as above or below a laboratory reporting limit or undetected are considered censored values and have a " $>$," "<," or " $U$ " in their remark field. A " $>$ " in the remark field indicates that the actual value is known to be greater than the value in the parameter field for that constituent. A " $<$ " in the remark field indicates the actual value is known to be less than the value in the parameter field for that constituent, whereas a " $U$ " in the remark field indicates the material was specifically analyzed for, but was undetected (Maddy and others, 1990, p. 2-14). There are several methods for determining the concentration of a given constituent in water; therefore, several different laboratory reporting limits may be present for a single constituent.

To load the data set into a spread sheet or other software package, insert the file as ASCII text, tabdelimited data. For best results, if possible, be sure to import the parameter field for the site identification number (staid, table 1) as character text to preserve the leading zeros for site identification numbers.

An ASCII text version of table 1 is included on the data diskette. The file is named table1.txt and is provided so table 1 can be printed out and easily referenced while working with the nutrient data set.

The data set also is available for retrieval on the World Wide Web at: http://webserver.cr.usgs.gov/ nawqa/ucol/ucol_home.html

\section{REFERENCES CITED}

Apodaca, L.E., Driver, N.E., Stephens, V.C., and Spahr, N.E., 1996, Environmental setting and implications on water quality, Upper Colorado River Basin, Colorado and Utah: U.S. Geological Survey Water-Resources Investigations Report 95-4263, 33 p.

Bureau of Census, 1990, 1992, census of population and housing: Washington, D.C., U.S. Department of Commerce, data on CD-ROM.

Driver, N.E., 1994, National Water-Quality Assessment Program-Upper Colorado River Basin: U.S. Geological Survey Open-File Report 94-102, 2 p. [Water fact sheet.]

Maddy, D.V., Lopp, L.E., Jackson, D.L., Coupe, R.H., and Schertz, T.L., 1990, National Water Information System user's manual-v. 2, chap. 2, Waterquality system: U.S. Geological Survey Open-File Report 89-617, $222 \mathrm{p}$.

Mueller, D.K., Hamilton, P.A., Helsel, D.R., Hitt, K.J., and Ruddy, B.C., 1995, Nutrients in ground water and surface water of the United States-An analysis of data through 1992: U.S. Geological Survey WaterResources Investigations Report 95-4031, 74 p.

Spahr, N.E., Driver, N.E., and Stephens, V.C., 1996, The Upper Colorado River Basin National WaterQuality Assessment Program surface-watermonitoring network: U.S. Geological Survey Fact Sheet FS-191-96, 4 p. [Water fact sheet.]

Spahr, N.E., and Wynn, K.H., 1997, Nitrogen and phosphorus in surface waters of the Upper Colorado River Basin: Journal of the American Water Resources Association, v. 33, no. 3, p. 547-560. 